\title{
HoW, IF AT ALL, SHOULd THE LAW OF TRADEMARKS ADAPT TO THE RISE OF SENSORY MARKETING?
}

\author{
MICHAL WOLANGIEWICZ*
}

\section{INTRODUCTION}

It is an undisputed fact that contemporary branding strategies ${ }^{1}$ rely on much more than words and logos to capture the attention of consumers. Current evolutions in branding practice are causing businesses to experiment with 'non-traditional' (exotic) signs - scents, sounds, colours, flavours and even textures (haptic trademarks). In fact, we have entered new era of advertising in which companies and especially marketers commonly take advantage of sense-based marketing.

By using academic opinion and case law, this paper argues that trademark law is suitable for the regulation of sensory marketing. Namely, it will demonstrate that the courts in the EU and in the US lack judicial imagination given their reluctance to acknowledge the registrability of some non-conventional signs (with the emphasis put mainly on olfactories) and that the time is ripe for the courts to recognise the progress in branding which was caused by digital revolution.

It will be argued that new technologies and a general digitisation of the trademark register would allow legal authorities to align with contemporary branding practices and technological developments. These technological means seem sensible, especially considering the revisions in Article 3 and Recital 13 of the new EU Directive ${ }^{2}$, which have attempted to accommodate non-conventional signs by removing the graphical representation requirement. ${ }^{3}$

DOI: $10.1515 /$ wrlae-2018-0016

*Graduate of the London School of Economics (LSE) and Wroclaw University, trainee lawyer at Linklaters, michal.wolangiewicz@gmail.com.

${ }^{1}$ Multi-sensory brand-experience strategies that take place when more than one of the five senses affects the consumer's perception of the product/service.

2 The Directive (EU) 2015/2436 of the European Parliament and of The Council of 16 December 2015 to approximate the laws of the Member States relating to trademarks.

${ }^{3}$ Regardless, the requirement of clear and precise representation and all the Sieckmann criteria remain. 


\section{I. 'WHY IS THERE A SMELL OF FRESHLY-BAKED BREAD AROUND THE BREAD COUNTER? TO MAKE US BUY THE STUFF' ${ }^{4}$}

Nowadays, marketers are trying to attract customers with multisensory brand-experience influencing not only sight and hearing but all of the five human senses.

The use of the sense of smell which is related to pleasure and wellbeing $^{5}$, makes a particularly powerful tool. Patrick Süskind once famously wrote that 'Odours have a power of persuasion stronger than that of words, appearances, emotions, or will.' 6 Their utilisation in marketing has become of increasing importance to contemporary branding strategies due to the persuasive power that can be derived from it. Recent review of research on the impact of scent on consumer behaviour done by Rimkute et al. confirms that statement. ${ }^{7}$ Their search of literature focused on papers published between 1980 and 2015 in the fields of marketing and psychology and was conducted using electronic databases including ProQuest, EBSCO, ISI and Ovid. A total of 45 articles from 18 journals were found as a result of searching for keywords such as 'scent', 'odour', 'smell', 'olfactory cues', 'environmental fragrance', 'environmental cues', 'atmospherics' and 'environmental stimuli'. Nine (9) per cent of them were published during the 1980s and more than 56 per cent since the year 2000, which shows that the field is on the rise. ${ }^{8}$

There is nothing unexpected about that outcome. The work of academics correlates with the trend that is visible in the marketplace. More and more companies imbue products with odours in order to boost the brand recognition. ${ }^{9}$ Marketing information is no longer designed for the sole purpose of appealing to consumers' senses of vision and hearing. Marketing specialists are becoming convinced that persuasiveness can be achieved by targeting other senses. ${ }^{10}$ Experiential (sensory) marketing, which can be described as a cross-media (appealing to all five senses) promotional activity that focuses on the human mind, is a still new, but already well-established, branch of the field. ${ }^{11}$ As argued by Krishna et al., 'this approach to marketing is especially relevant in the service industries, which offer goods with high

\footnotetext{
${ }^{4}$ C Stoakes, Commercial Awareness (Christopher Stoakes Ltd 2014) 7.

${ }^{5}$ B Hultén, 'Sensory marketing: the multi-sensory brand-experience concept' (2011) 23.3 European Business Review 259.

${ }^{6}$ P Süskind, Perfume: The Story of a Murderer (1985).

${ }^{7}$ J Rimkute, C Moraes \& C Ferreira, 'The effects of scent on consumer behaviour' (2016) 40 International Journal of Consumer Studies 24-34.

8 ibid 25.

9 A Krishna, MO Lwin \& M Morrin, 'Product scent and memory' (2010) 37.1 Journal of Consumer Research 57.

${ }^{10}$ Lwin, M. O. \& M Morrin, 'Scenting movie theatre commercials: The impact of scent and pictures on brand evaluations and ad recall: Scented cinema ads' (2012) 11 Journal of Consumer Behaviour 264-272.

${ }^{11}$ Hultén (n 5).
} 
experiential and credence properties, although the evaluation of which is often difficult before consumption takes place.' ${ }^{12}$

Smell is particularly powerful in this regard because people do not perceive scents as marketing massages and, which follows, are not negatively biased (reacting with the usual resistance to advertisements). The cause stems from biology. Smell is the only sense that has a direct connection to a very important part of limbic system - amygdala, the complex region of the brain connecting the brainstem with areas that control the expression of innate behaviours and associated physiological responses.

More precisely, as pointed out by Hirsch, ${ }^{13}$ smell is directly linked to emotions due to the fact the nose and olfactory structures are connected to the prepiriform cortex, the emotional centre of the brain, i.e. the aforementioned amygdala. This explains the phenomenon called olfactory-evoked recall, 'which occurs when an odour stimulates the vivid recall of a memory or scene from the past.' ${ }^{14}$ And this 'unique function of olfaction, which as opposed to the other human senses has an unparalleled ability to evoke memories. This so-called Proustian memory has a rapid impact on the subconscious and the power to generate strong memory associations.' 15

Direct connection to amygdala allows also the perception of scent to, unlike any other stimuli, affect consumers without them being aware of it (being perceived through pre-attentive processing). Hence, 'it can achieve a (positive) response without distracting from attention given to other stimuli for example, visual information', as pointed out by Davies et al. in their seminal article on use of the ambient scent in commerce. ${ }^{16}$ In simpler words, as put in turn by Rimkute et al., 'consumers may not be aware of the presence of the olfactory cue because it operates below the level of perception or at very low concentration. Even if consumers are able to detect the scent, they may still not be aware of its influential nature.' ${ }^{17}$

An experiment conducted by Krishna with May O. Lwin, of Singapore's Nanyang Technological University, and Maureen Morrin, then of Rutgers University, is one of many good examples. They found that imbuing pencils with the unusual scent of tea tree oil increased research subjects' (people's) ability to remember the pencils' brand and other details. Whereas those given unscented pencils experienced a 73 per cent decline in the information they could recall two weeks after exposure, people given teatree-imbued pencils experienced a decline of just 8 per cent. ${ }^{18}$ Last but not least, in a recent study of positive emotions transfer between humans by olfactory means, de Groot et al. (2015) found that happiness can be transferred among people by means of smells (suggestive evidence), and not

\footnotetext{
${ }^{12}$ A Krishna, MO Lwin \& M Morrin (n 9) 57.

${ }^{13}$ AR Hirsch, 'Effects of ambient odors on slot-machine usage in a Las Vegas casino' (1995) 12 Psychology and Marketing 585-594.

14 ibid.

${ }^{15}$ S Karapapa, 'Registering Scents as Community Trademarks' (2010) 100.6 The Trademark Reporter 1335-1359, 1336.

${ }^{16}$ BJ Davies, D Kooijman \& P Ward, 'The Sweet Smell of Success: Olfaction in Retailing' (2003) Journal of Marketing Management 611, 616.

${ }^{17}$ Rimkute, Moraes \& Ferreira (n 7).

18 The Science of Sensory Marketing. Harvard Business Review, March 2015 <https://hbr.org/2015/03/the-science-of-sensory-marketing $>$.
} 
only by 'smiling, cheering, or hugging someone using the respective modalities of vision, hearing, and touch.' 19

Thanks to all of the biological factors mentioned above, scents help marketers to develop a relationship between a company and a purchaser. Brand evaluations disclose that scents lead to greater reactions to the brand stimuli, brand recall and recognition. ${ }^{20}$ 'They're effectively adding a scent logo to their establishment.' 21 In other words, they have 'a potentially powerful point from which to develop loyalty to the retail brand and/or store. $^{22}$

Of course, the same can also be said about other senses. And, in fact, marketers use the potential of all of them. The sense of sound affects emotions and feelings and impacts consumer's brand experiences directly. 'Music in service settings can reduce even relatively extreme emotions such as intense anxiety. ${ }^{23}$ The sense of taste is very distinct emotional sense which interacts with other senses, especially smell while eating. The sense of touch in turn is, of course, the tactile and relates to feelings about a product through physical interaction. ${ }^{24}$ It follows that it naturally influences customers' attitudes about it. Hence, there is nothing shocking in the fact that touching 'a product has been found to increase attitudes and purchase intentions toward the product and to increase the confidence in the evaluation of these products. ${ }^{25}$

\section{THE RELATIONSHIP BETWEEN SENSORY MARKETING AND TRADEMARK LAW}

Experiential marketing is on the rise as brand images such as $\mathrm{Nike}^{26}$, Apple, Sturbucks, just to name a few, has showed. Accordingly, the primary role of trademarks has radically evolved lately. They are no longer just signs of origin. Their role goes beyond that. Trademarks are now an important part of the brand formation. ${ }^{27}$ In response to the recent development of sensory marketing they started to protect unconventional marks which are not original

\footnotetext{
19 JHB de Groot, MAM Smeets, MJ Rowson, PJ Bulsing, CG Blonk, JE Wilkinson \& GR Semin, 'A Sniff of Happiness' (2015) 26 Psychological Science’ 684-700, 684

${ }^{20} \mathrm{KD}$ Bradford \& DM Desrochers, The Use of Scents to Influence Consumers: The Sense of Using Scents to Make Cents’ (2009) 90 Journal of Business Ethics 9.

21 'The smell of commerce: How companies use scents to sell their products' Independent (15 August 2011) <http://www.independent.co.uk/news/media/advertising/the-smell-ofcommerce-how-companies-use-scents-to-sell-their-products-2338142.html> accessed 16.02.2017.

${ }^{22}$ Davies, Kooijman \& Ward (n 16), 622-623.

${ }^{23}$ FV Garlin \& K Owen, 'Setting the tone with a tune: a meta-analytic review of the effects of background music in retail settings' (2006) 59 Journal of Business Research 756.

${ }^{24}$ Hultén (n 5), 259.

25 J Peck \& J Wiggins, 'It just feels good: customers' affective response to touch and its influence on persuasion' (2006) 70 Journal of Marketing 55.

${ }^{26}$ Interestingly, a study run by Nike showed that adding scents to their stores increased intent to purchase by 80 per cent.

27 Trademarks are now an important part of the brand formation. Brands, as was show above, operate on all kinds of marketing levels, not just as vehicles for information about origin. And trademarks started to facilitate it.
} 
subjects of trademark law. Consequently, contemporary trademark regulations protect not only visual signs, they do much more facilitating the huge change in marketing which is going on right now.

Nowadays, marketers work more holistically. They create strategies for the companies and the whole range of their products, rather than a single commodity. As pointed out by Arvidsson, they use many techniques to insert their brand into consumers' everyday life. The tendency is that marketing is moving away from the original media advertising to a more interactive or cross-media approach. ${ }^{28}$ And this new communication method in marketing has its roots in trademarks that facilitate the development of intangible brand images like those of Red Bull, Vans or Persols. As for scents for instance, Abercrombie \& Fitch, Lush, and MUJI, for example, created a brand scent for uses in their retail stores, on textiles and employee perfume. 'Singapore Airlines [in turn] integrated its signature scent into its communication concept as perfume, ambient scent and refreshing tissues.' ${ }^{29}$

However, it should be emphasised that a trademark is something completely different than brand. A trademark is mark itself which 'may consist of any signs, in particular words, including personal names, or designs, letters, numerals, colours, the shape of goods or of the packaging of goods, or sounds', as new legal definition goes. ${ }^{30}$ Brand in turn is a much wider term and relates, at least in business meaning, to the overall image of the company, or to put it more simply, it, "is what your prospects thinks of when her or she hears your brand name.' 31,32

According to the dominant economic view, the primary goal of trademarks is 'to promote economic efficiency.' 33 Trademarks, as Anne Barron rightly indicates, promote efficiency by saving consumers search costs (thereby releasing time and energy for productive pursuits) and incentivising producers to invest in quality (since consumers will only want to search for products whose quality has pleased them in the past). Regardless, traditional underpinning of trademark law, i.e. the theory of trademark as the designation of the source, does not tell the whole story. ${ }^{34}$ The business idea behind trademarks boils down to the willingness to being positively distinguished from competitors. Another is to make consumers recall the brand while they do the shopping or look for the service. ${ }^{35}$ It is quite simple and clear. It follows that, in an ever-growing competitive market, corresponding trademark protections ought to react where scents are usually not the product feature and

\footnotetext{
${ }^{28}$ A Arvidsson, 'Brand Value' (2006) 13 Brand Management 188.

${ }^{29}$ M Girard, A Girard, A-C Suppin, S Bartsch 'The Scentscape: An Integrative Framework Describing Scents in Servicescapes' (2016) 9 Journal of Business Market Management 597 622.

${ }^{30}$ See Art 3 of the Directive (EU) 2015/2436 of the European Parliament and of The Council of 16 December 2015 to approximate the laws of the Member States relating to trade marks.

${ }^{31} \mathrm{~J}$ McLaughlin, What is brand, anyway? Forbes (2011)

<http://www.forbes.com/sites/jerrymclaughlin/2011/12/21/what-is-a-brandanyway/\#be895162aa4b> accessed 21.02.2017.

32 Traditional Trademark is analogous to the name of a firm, e.g. 'Starbucks'. Meanwhile, the brand is analogous to the whole array of associations that cluster around that name in other people's minds.

${ }^{33}$ B Beebe, 'Search and Persuasion in Trademark Law' (2005) 103 Michigan Law Review 2030.

34 ibid.

${ }^{35}$ Arvidsson (n 28) 192.
} 
if a trader has demonstrated distinctiveness as the use of scents constitutes a unique marketing technique that should be granted a monopoly.

\section{REGISTRABILITY OF SENSORY MARKS}

Non-traditional marks are often difficult to protect due to the fact they incorporate features that perform a function rather than indicate the source of a given commodity or a service. Despite this fact, some of them, especially colours and sounds, have paved their way to trademark registration proving their ability of being 'distinctive' and able to function as an 'indicator of source'.

As for sounds - no matter whether song, ringtone, sound of a motor, click or snap - they are very memorable and often satisfying, which is why companies often try to protect them as being associated with their brand and overall marketing strategy. ${ }^{36}$ And, in fact, distinctive sounds have been registered as trademarks in many countries. In the US, a wide range of sound marks have been registered, such as Tarzan yell ${ }^{37}$, the tone at the end of an Intel commercial, Yahoo! yodel, and the lion's roar at the beginning of MetroGoldwyn-Meyer (MGM) movies ${ }^{38}$. In Germany AT\&T, Deutsche Telekom and Nokia have registered many ringtones. In the UK, amongst many others, the 'sound of a speaking clock' has been granted protection in favour of British Telecom. ${ }^{39}$ There is nothing unexpected about it. As the Court stated in MGM's case, in the situation when 'the sound mark involves music in the traditional sense of the word, there is an obvious way to represent it graphically, namely by representing the theme or composition to be registered as a sound mark by standard musical notation, i.e. on or between the lines of a stave, giving the clef, bars, key and, if applicable, the tempo. ${ }^{40}$ When the mark is not music but animal noise for example, things are more complicated. Although, thanks to modern technology granting protection to that kind of sound is possible. For example, in the case of lion's roar it was spectrogram (sonogram), 'a three-dimensional depiction of the distribution of a signal's frequency content (blackening) versus frequency (vertical axis) and time (horizontal axis) ${ }^{41}$, which allowed the specific sound to be depicted precisely and objectively enough for the purpose of the registration.

At the same time, only a few scents have been granted this privilege so far. In the UK there are only two instances in which intelectual-property office has trademarked a scent. One involved Unicorn Products, a Londonbased maker of sports equipment, and its flights for darts redolent of 'the

\footnotetext{
${ }^{36}$ E Byron, 'The Search for Sweet Sounds That Sell' The Wall Street Journal (24 October 2012).

${ }^{37}$ Edgar Rice Burroughs Inc. v OHIM; Case R 708/2006-4.

${ }^{38}$ Case R 781/1999-4.

${ }^{39}$ L Daniel, 'Distinctive sounds like the MGM lion's roar protected by law' Montreal Gazette (February 10 2012).

${ }^{40}$ Case R 781/1999-4, para 21.

41 ibid., para 26.
} 
strong smell of bitter beer' 42 . The second related to 'a floral fragrance/scent reminiscent of roses as applied to tyres' produced by Japan's Sumitomo Rubber Co. $^{43}$ (see more on the legal position of scents further).

The same situation relates to another possible type of sensory marks - taste, which is nothing more than the perception of the combination of scent and the five tastes on the tongue and scents contribute for approximately eighty percent to taste. Accordingly, the combination of the five tastes contributes just approximately twenty percent which explains why food becomes relatively flavourless when we are congested. ${ }^{44}$

The bias against registering flavours is quite similar to that regarding scents. Why is that? There are three main reasons. The first stems from the fact that protecting taste marks may not be that important from the outset because flavours are covered by trade secrets and patents protection ${ }^{4546}$. The second is intertwined with the former and concerns the functionality doctrine preventing producers from protecting specific features of a product ${ }^{47}$. It is of utmost importance because if 'a product's functional features could be used as trademarks, ... a monopoly over such features could be obtained without regard to whether they qualify as patents and could be extended forever (because trademarks may be renewed in perpetuity). ${ }^{48}$ It is easy to imagine such a situation in the world of food. The first vendor who popularized a flavour would be able to prevent all others from replicating the taste. Such a situation would very negatively affect the innovation in the whole industry given the fact there are limited number of tastes that people find appealing.

The third and last one concerns distinctiveness and the simple fact that the human being is capable of distinguishing just four tastes: sweet, sour, salty and bitter. ${ }^{49}$ All the rest of the entire range of tastes is formed through a combination of these basic tastes and food scents. Thus, a man with closed nose and eyes is not able to tell the difference between, say, green pea purée and pumpkin purée. ${ }^{50}$ In any case, the issue with distinctiveness has been recently emphasized by the Judge of the US District Court for the Southern

${ }^{42}$ UK Reg. No. 2001416/filing date 31.10.1994. See J Gershmann, 'Eau de Fracking? Companies Try to Trademark Scents' The Wall Street Journal (14 April 2015).

${ }^{43}$ The mark was later transferred to Dunlop Tyres.

44 C Binns, 'How we smell' (2006) LifeScience. <http://www.livescience.com/10457smell.html> accessed 19.03.2017.

${ }^{45}$ As stated by the Court in Qualitex: 'It is the province of patent law, not trademark law, to encourage invention by granting inventors a monopoly over new product designs or functions for a limited time ... after which competitors are free to use the innovation.'

46 The most famous example is Coca-Cola which recipe is protected as a trade secret. Of course, it does not stop rival companies from reproducing identical taste their own way but so far no one has been able to precisely replicate the flavour of Atlanta-based company's iconic beverage.

47 The feature of the product is not registerable if it is crucial to the use or purpose of it, or the feature affects the cost or quality of the article. What follows, in the case of food the taste is almost always functional.

${ }^{48}$ Qualitex Co. v Jacobson Prods. Co., 514 U.S. 159, 164 (1995).

49 Sometimes it is claimed that there is a fifth one, the taste of monosodium glutamate (umami) which is used by food producers as a taste enhancer.

${ }^{50}$ A Zaitseva, 'Challenging Aspects of Protecting of Non-Traditional Trademarks: The Five Senses and Trademarks' IPWatchdog (02.03.2017) <http://www.ipwatchdog.com/2017/02/03/challenging-aspects-non-traditional-trademarksfive-senses/id=77676/> accessed 21.03.2017. 
District of Texas, Gregg Costa, in New York Pizzeria, Inc. v. Syal et al. where he noted that 'as with colours, it is unlikely that flavours can ever be inherently distinctive, because they do not automatically suggest a product's source. ${ }^{51}$ The reason is obvious: tastes acquire distinctiveness or 'secondary meaning' only after costumers' first contact with them when they learn to associate the taste with its source.

Practically, however, the most important problem with registering tastes as trademarks concerns functionality. As stated by Judge Costa in the final remarks of his judgement, 'functional product features are not protectable.' ${ }^{52}$ And this 'hurdle is ... possibly insurmountable in the case of food. People eat, of course, to prevent hunger. But the other main attribute of food is its flavour, especially restaurant food for which customers are paying a premium beyond what it would take to simply satisfy their basic hunger needs. The flavour of food undoubtedly affects its quality, and is therefore a functional element of the product. ${ }^{53}$

Other interesting cases relate to the registrability of tastes as trademarks concern medicines. A well-known example is Eli Lilly \& Co's case in which the pharmaceutical company tried to obtain the trademark protection for the taste of artificial strawberries. It was rejected by the OHIM stating that any producer of drugs 'is entitled to add the flavour of artificial strawberries to those products for the purpose of disguising any unpleasant taste that they might otherwise have or simply for the purpose of making them pleasant to taste... ${ }^{54}$ More precisely, the taste mark was 'devoid of distinctive character because, in relation to pharmaceutical preparations, the taste of strawberry is one of many common tastes used as a flavouring to mask the otherwise unpleasant taste of the products. ... [The] mark will be wholly overlooked because there is no reason for the consumer to taste these products. ${ }^{55}$ Thus, again, trademark protection was not granted due to functionality and the probable anti-competitive effects of registration. However, unlike in the case of New York's pizza, the Court noted that the flavour was not irrelevant for registrability as a trademark because it can only be ascertained after purchase. In the reasonable view of the Judges, '[t]he doctor who prescribes the product will prescribe a pleasant tasting product, rather than other pharmaceutical products with equivalent medical indications, because he knows that the consumer will accept it more readily due to its taste. ${ }^{56}$

A very similar attempt by N.V. Organon to register an orange flavour for antidepressants was rejected by the USPTO, again, on functionality and distinctiveness grounds. First and foremost, the Trademark Trials and Appeals Court (TTAB) stressed that it is difficult to accept the registrability of flavours as a trademarks when consumers only taste goods after purchase. ${ }^{57}$ As Judges rightly pointed out, 'it would not be expected that prescribed

\footnotetext{
${ }^{51}$ New York Pizzeria, Inc. v Syal et al, No. 3:2013cv00335.

52 ibid.

53 ibid.

${ }^{54}$ Eli Lilly \& Co’s Community Trade Mark Application, Case R 120/2001-2.

55 ibid.

56 ibid.

${ }^{57}$ In re NV Organon, Serial No. 76467774.
} 
antidepressants would be tasted prior to purchase so that a consumer, in conjunction with a physician, could distinguish one antidepressant from another on the basis of taste. ... Consequently, it is difficult to fathom exactly how a flavour could function as a source indicator in the classic sense, unlike the situation with other non-traditional trademarks such as colour, sound and smell, to which consumers may be exposed prior to purchase. ${ }^{58}$

To put it more simply, consumers do not see flavour in a product as a trademark. It is rather just another feature of the product for them. Moreover, given the fact medicines generally have 'a disagreeable taste', flavouring 'performs a utilitarian function that cannot be monopolized without hindering competition in the pharmaceutical trade. ${ }^{59}$ Namely, because of the significant popularity of orange flavour in the world of drugs, competitors would be at a disadvantage if one firm was granted an exclusive use. Hence, provided that an orange flavour is used in numerous medicines and, which follows, it is not inherently distinctive, 'consumers would not view the orange flavour of an antidepressant tablet or pill as a trademark; rather, they would consider it only as just another feature of the medication, making it palatable.' 60 Consequently, the refusal to register under the Lanham Act was not affirmed by TTAB on the ground of the fact the applicant did not introduced any evidence of acquired distinctiveness.

As for removal of the graphical representation requirement, it will not change much in terms of registering tastes, because the SCT has already reported that it 'was satisfied by using a written description of the taste and an indication that it concerns a taste mark' ${ }^{\prime}$. What is more, as rightly stated by Sharon Daboul, a trademark attorney for EIP, 'removing the requirement of graphical representation does not affect the requirement that the trademark still be represented in some manner. Applicants will have to come up with a way of representing the trademark that is clear and precise, for both the registry and third-parties, and this has not been achieved to date. The representation will have to be durable, and tastes can change over time; it will also have to be easily accessible to others, and it is hard to see how a taste can be accessible to the public via the Internet.' 62

Last but not least, haptic marks are probably the least common, but as any other distinctive indication of source, capable of being protected by trademark law. As a matter of fact, in 2006 the International Trademark Association (INTA) adopted 'a resolution supporting the recognition and registration of 'touch' marks' ${ }^{63}$, but in spite of that, only few haptic marks were granted trademark protection. The reason is, in practice, that 'it is very difficult to separate the way something feels with the function that texture

\footnotetext{
58 ibid.

59 ibid.

60 ibid.

61 'Smell, Sound and Taste - Getting a Sense of Non-Traditional Marks' WIPO Magazine (February 2002) <http://www.wipo.int/wipo_magazine/en/2009/01/article_0003.html accessed $>21.03 .2017$.

${ }^{62} \mathrm{~T}$ Lince, 'Taste trademarks set to remain on the shelf' (2014) World Trademark Review (07.11.2014) <http://www.worldtrademarkreview.com/blog/detail.aspx?g=d1 f0f1be-bd2b429a-bab5-3d65f184fc30> accessed 21.03.2017.

${ }^{63}$ B Wassom, 'A Distinctive Touch: Augmented Textures and Haptic Trademarks' $(2011)<$ http://www.wassom.com/a-distinctive-touch-augmented-textures-and-haptic-

trademarks.html> accessed 19.03.2017.
} 
performs - and to come up with a texture that is truly distinctive of one product as opposed to other brands within the same category of products. ${ }^{64}$ Well-known examples come from the US where American Wholesale Wine\&Spirits has registered 'a velvet textured covering on the surface of a bottle of wine', Touchdown Marketing has obtained trademark protection for 'pebble-grain texture' of its basketball-like cologne flacon and Fresh, Inc. has achieved the same with regard to the 'cotton-textured paper' wrapping its soap. ${ }^{65}$

Should law be as strict as it is with regard to non-traditional marks, and especially scents? There is an important ethical argument against easier access to trademark protection for scents. Affecting consumers' judgment below the subconscious level may cast some doubt on the easier-accessproposal. As we mentioned above, customers are simply not aware of the influential nature of scent what makes them susceptible to manipulation. ${ }^{66}$ Hence, the use of scents for marketing purposes is by many regarded as a form of subliminal nudging. And according to European Union law, as pointed out by Rimkute et al., 'the subliminal advertising is prohibited in audio-visual media, so there is a need for ethical analyses and debates regarding the use of scent in service and retail marketing. ${ }^{67}$

On the other hand, one can argue that customers should choose to purchase a product on a rational and thoughtful basis, not because of the wave of emotions contrived by canny marketers. ${ }^{68}$ But any other marks including colours and sounds influence our subconscious too. Reducting to the absurdity: should we really annul marriages owing to the fact spouses used aphrodisiacs on the first date?

Another thing is that the lack of trademark protection will not stop companies from using scents as their marketing tool anyway. We can resent the fact that marketers invade another area of perception not so far affected by branded messages but this is just another effect (side effect?) of the economic development. If we do grant protection to companies investing in brands based on colours and sounds, why should we be so restrictive for those being aware that three-fourths of our emotions during the day are generated by smell? $?^{69}$ Trademarks are generally justified on the basis that they serve competition by enabling the products that consumers want to succeed in the marketplace against those that consumers do not want because they were disappointed with them beforehand. This presupposes that consumers can find the products they actually want. But do smells and other 'exotic' marks help them to find those products?

\footnotetext{
${ }^{64}$ ibid.

65 ibid.

${ }^{66}$ Bradford \& Desrochers (n 20) 141-153.

${ }^{67}$ Rimkute, Moraes \& Ferreira (n 7) 33.

${ }^{68} \mathrm{R}$ Brown jr, (1948) 'Advertising and the Public Interest: Legal Protection of Trade Symbols' (1948) 57 Yale Law Journal 1182.

${ }^{69}$ M Lindstroem, Brand Sense: Build Powerful Brands Through Touch, Taste, Smell, Sight and Sound (Free Press 2005).
} 


\section{OUTDATED Legal REALITY?}

What are the legal concerns about granting trademark protection to olfactories and other sensory marks? What is general legal approach to this matter?

The US is presumably the most lenient as far as registering nontraditional marks is concerned. It was the first country in the world which actually accepted the registration of a smell trademark. In 1990 in re Clarke the description 'high impact, fresh floral fragrance reminiscent of Plumeria blossoms' was accepted as sufficiently the smell for sewing thread and embroidery yarn. ${ }^{70}$ Later, the USPTO changed its approach to registering scent marks, it no longer requires the applicant to submit a drawing but a specimen and a written description. Plus, as in case of any other US trademark, one needs to show evidence of use and secondary meaning but there is no requirement of graphical representation. ${ }^{71}$ Thanks to that 'the US have been generous ever since in registering all kinds of non-traditional marks. ${ }^{72}$ It was confirmed in 1995 in the case Qualitex Co. v Jacobson Products Co. by the Supreme Court ${ }^{73}$ in which a colour ${ }^{74}$ was deemed by the Court as being able to meet the legal requirements for trademark registration under the Lanham Act, provided that it has acquired secondary meaning in the market. ${ }^{75}$

As an important side note, it is worth mentioning that in Qualitex the defendant made two general arguments concerning the registrability of colours. The first said that the use of colour as a trademark would produce uncertainty and countless disputes about what shades a competition could use. The second pointed out that colours were of limited supply. The Court found them not sufficient to justify a special legal rule preventing colour alone from serving as a trademark. Regarding the first one - Judges were not convinced that a colour is special in terms of it distinctiveness. Justice Breyer who delivered the opinion of the Court compared similarity of colours to that of two words that can confuse customers such as 'Bonamine' and 'Dramamine' (motion sickness remedies), 'Huggies' and 'Dougies' (diapers), 'Cheracol' and 'Syrocol' (cough syrup), or 'Cyclone' and 'Tornado' (wire fences). As for the latter, it was unpersuasive for the Court because, as pointed out by Breyer $\mathrm{J}$, it was based 'on an occasional problem to justify a blanket

\footnotetext{
${ }^{70}$ In re Clarke 17 U.S.P.Q. 2d (BNA) 1238 (T.T.A.B. 1990).

${ }^{71}$ D Friedmann, 'EU Opens Door for Sound Marks: Will Scent Marks Follow?' (2015) 10.12 Journal of Intellectual Property Law \& Practice 931, 931-939.

72 ibid.

${ }^{73}$ Qualitex Co. v Jacobson Products Co., 514 U.S. 159 (1995) 162.

${ }^{74}$ The case 'grows out of petitioner Qualitex Company's use (since the 1950's) of a special shade of green gold colour on the pads that it makes and sells to dry cleaning firms for use on dry cleaning presses. In 1989 respondent Jacobson Products (a Qualitex rival) began to sell its own press pads to dry cleaning firms; and it coloured those pads a similar green gold. In 1991 Qualitex registered the special green gold colour on press pads with the Patent and Trademark Office as a trademark.'

${ }^{75}$ As Breyer put it in his opinion on writ of certoriari to the US Court of Appeals for the Ninth Circuit ' $[\mathrm{w}] \mathrm{e}$ cannot find in the basic objectives of trademark law any obvious theoretical objection to the use of colour alone as a trademark, where that colour has attained secondary meaning and therefore identifies and distinguishes a particular brand (and thus indicates its source).'
} 
prohibition. When a colour serves as a mark, normally alternative colours will likely be available for similar use by others.'

All Member States of the European Union, like the US, are parties to the Paris Convention for the Protection of Industrial Property, so they have to accept registration of any trademark, including non-traditional marks that have already been registered in another Paris Union state. Regardless, there are still two main obstacles for some 'exotic' marks, and especially scent marks present in some Member States. Firstly, the requirement of graphical representation (which is removed by the new Directive but still applicable in some domestic legal systems of Member States). Secondly, the condition that the mark must be capable of distinguishing. The requirement of graphical representation, at least in fact, presents itself as the most significant barrier to seeking registration of a trademark (at least until technology catches up). Actually, as Friedmann put it, this is 'the requirement [that] lulled the registration of scent marks into a slumber in the EU between 2002 and 2005. ${ }^{76}$

It was reinforced by the European Court of Justice in 2002 in case of Ralf Sieckmann vs Deutsches Patent-und Markenamt. ${ }^{77}$ The Court - which provided representability requirements in order to ensure legal certainty found that graphical representation 'must enable the sign to be represented visually, particularly by means of images, lines or characters. The representation must be 'clear, precise, self- contained, easily accessible, intelligible, durable and objective.' ${ }^{78}$ Consequently, the ways in which Sieckman described the scent, ie the pure chemical substance 'mthylcinnamate' with the formula ' $\mathrm{C} 6 \mathrm{H} 5-\mathrm{CH}=\mathrm{CHCOOCH} 3$ ' or 'balsamically fruity with a slight hint of cinnamon' have been rejected. AG Ruiz-Jarabo Colomer held that the condition of graphic representation was necessary for judicial certainty constituting a bureaucratic, definitional and informational function. The chemical formula only represented the substance of the product, which the public would find difficult to comprehend, undermining these functions. However, it was argued that everyone with a basic knowledge of chemistry would be able to recognise the scent in the formula. Paradoxically, in another case concerning the non-traditional sign of sound, AG Ruiz-Jarabo Colomer acknowledged that not all people can read musical score, but that the immediate comprehension of such scores is not necessary. ${ }^{79}$ It is thus questionable why he did not apply the same reasoning to scents. Nevertheless, the Advocate General in Sieckmann went on to state that the written description provided was too subjective to reflect an accurate smell. In addition, the supply of a sample would decay over time and could therefore not be kept on a trademark register. ${ }^{80}$

\footnotetext{
${ }^{76}$ Friedmann (n 71) 931.

${ }^{77}$ No. C-273/00, November 6, 2001.

${ }^{78}$ Case- 273/00 Sieckmann v Deutsches Patent-und Markenamt [2002] ECR I-11737, paras 40 and 69.

${ }^{79}$ ibid, para 42.

80 'The smell of commerce: How companies use scents to sell their products' Independent (15 August 2011) <http://www.independent.co.uk/news/media/advertising/the-smell-ofcommerce-how-companies-use-scents-to-sell-their-products-2338142.html $>\quad$ accessed 16.02.2017.
} 
Likewise, in Eden v OHIM ${ }^{81}$ the claimant unsuccessfully applied to register the scent of a ripe strawberry accompanied by an image of a strawberry in relation to a large range of goods. The application was refused on grounds that the mark was neither capable of being graphically represented being, in part, a smell, nor distinctive for the goods in question. Since the description 'smell of ripe strawberries' could refer to several varieties and therefore to several distinct smells, it is neither unequivocal nor precise and does not eliminate all elements of subjectivity in the process of identifying and perceiving the sign claimed.

Professor Maniatis claimed that although a scent may be registrable, it does not belong on the register due to the risk of confusion that the average consumer is likely to encounter when expected to identify a scent as a badge of origin, and the strong evidence of recognition required. ${ }^{82} \mathrm{~A}$ response to this argument is the Sense of Smell Institute's finding that the human nose can distinguish up to 10,000 scent qualities. ${ }^{83}$ This suggests that the risk of confusion on the part of a consumer is perhaps not as severe as predicted.

Notwithstanding, what has been indisposing legislators as much from facilitating the easier access to trademark protection for scents is its alleged contradiction with the traditional purpose of trademark law, i.e. allowing consumers to differentiate similar commodities from different sources/origins. Another problem derives from the former. According to the prevailing legal doctrine, the mark must be distinctive to serve a trademark function of indicating the origin of the commodity or the service. And there is some doubt whether smell signs are capable of distinguishing products, ie possessing a distinctive character (according to trademark law of different jursidictions trademarks which are devoid of any distinctive character shall not be registered ${ }^{84}$ ).

The requirement of graphical representation which is included in Art 1(1) of the UK Trade Marks Act of 1994, but as mentioned above, the new Article 3 and Recital 13 of the new EU Directive have already accommodated non-conventional signs by removing the graphical representation requirement (as recommended by the Max Planck Institute) and adding colours and sounds to non-exhaustive list of possible national and EU trademarks: ${ }^{85}$

Article 3 Directive:

"A trade mark may consist of any signs, in particular words, including personal names, or designs, letters, numerals, colours, the shape of goods or of the packaging of goods, or sounds, provided that such signs are capable of:

(a) distinguishing the goods or services of one undertaking from those of other undertakings; and

(b) being represented on the register in a manner which enables the competent authorities and the public to determine the clear and precise subject matter of the protection afforded to its proprietor." [emphasis added]

\footnotetext{
${ }^{81}$ Case T-305/04 (CFI (Third Chamber) 27 October 2005).

${ }^{82}$ E Mezulanik, 'The Status of Scents as Trademarks: An International Perspective' (2012) IntaBulletin

<http://www.inta.org/INTABulletin/Pages/TheStatusofScentsasTrademarksAnInternational

Perspective.aspx> accessed 15 February 2017.

${ }^{83}$ Girard et al (n 29) 597-622.

${ }^{84}$ Directive 2015/2436 of 16 December 2015, Art 4.

${ }^{85}$ Friedmann (n 71) 931.
} 
Recital 13 Directive (old Recital 8 Directive):

"To this end, it is necessary to list examples of signs which are capable of constituting a trade mark, provided that such signs are capable of distinguishing the goods or services of one undertaking from those of other undertakings. In order to fulfil the objectives of the registration system for trademarks, namely to ensure legal certainty and sound administration, it is also essential to require that the sign is capable of being represented in a manner which is clear, precise, self-contained, easily accessible, intelligible, durable and objective. A sign should therefore be permitted to be represented in any appropriate form using generally available technology, and thus not necessarily by graphic means, as long as the representation offers satisfactory guarantees to that effect." [emphasis added]

It follows that, according to this piece of legislation at least, every mode of representability is permissible if it is in harmony with the remaining requirements stipulated in Sieckmann (ie has to be 'clear and precise, selfcontained, easily accessible, intelligible, durable and objective). ${ }^{86}$

Accordingly, the UK's lawmakers should pave the way for 'exotic' trademarks accordingly regardless of Brexit and its uncertain implications in law. Moreover, as in the new Directive, 'sounds' along with 'colours' should be added to the non-exhaustive lists of possible national trademarks. It would not be a ground-breaking decision. Sound recordings accompanying community trademark applications are already accepted by the EU Intellectual Property Office (EUIPO) as sound trademarks. Moreover, EUIPO, as pointed out by Friedmann in his seminal article addressing the future of scent marks, has already suggested that the digital representation of sounds would also be welcomed. ${ }^{87}$

Sanction of sound files is crucial for scents marks given the fact comparable technologies capable of identifying their different components (e.g. gas chromatography) and digital encoding are also available. ${ }^{88}$ 'The applicant can send such a digital file via the internet to the to the trade mark office, who can store, examine and publish it. The public, including competitors, can download the digital file from the trade mark office's database. They can then transform the digital file into a scent again by making use of a scent.' ${ }^{89}$ Additionally, using digital files for smells accompanied by a scent printer may be very promising as it will comply with the Sieckmann requirement using 'generally available technology'. ${ }^{90}$ As indicated by Friedmann, scent printers have been around for last sixty years but just recently they have become relevant in terms of registrability of trademarks. ${ }^{91}$

\footnotetext{
86 ibid.

87 ibid.

88 V Mackie, (2004/2005) 'Scent Marks. The Future of Canadian Trade-Mark Law' (2004/2005) Intellectual Property Journal 417, 438.

${ }^{89}$ Friedmann (n 71) 931-93.

90 ibid.

${ }^{91}$ In 1999 at the University of Huelva an XML Smell language that can standardise the way of transmission of scents by email, twitter, so forth was developed. In 2014 in turn at Harvard
} 
By using an 'electronic nose' in turn, which is a sensor that samples pattern recognition to generate and characterise, smells ${ }^{92}$ could also be used to provide courts with the requisite judicial imagination in granting trademark protection. Such a sensor would allow transfer of the scent onto the trademark register and the registrar could request a renewed submission of the scent to avoid its decay. Furthermore, the use of gas chromatography and mass spectroscopy, producing prints representing each separated and identified components of a scent could be adopted in facilitating the graphical representation of smells. ${ }^{93}$

One way or another, 'the competent authorities and the public [will be able] to determine the clear and precise subject matter of the protection afforded to its proprietor.' 94 Widely accepted identification systems like the Pantone system for colours, the 'Perfumery Radar' classifications system for perfumes, or RAL colour ${ }^{95}$ might be introduced in order to overcome the obstacle of recognising scents as indicators of commercial source. ${ }^{96}$ It is crucial, since as stressed by Friedmann, 'an era of blooming scent marks in the EU is contingent on the development of an international classification system for scent marks, similar to the Vienna Convention for figurative marks. ${ }^{97}$ As rightly stated by Professor Jehoram, it is as important as an easy access. $^{98}$

\section{CONCLUSION}

The whole area of marketing is no longer focused on allowing customers to physically experience brands. Most effective marketing strategies are generally much more sophisticated these days. Thanks to available technologies, marketers focus on the customers' experience with products of companies they are working for. Namely, '[w] hat all brands aspire to achieve through their marketing is to buy time in people's brains. The more time you have to spend in someone's brain in a positive way, the more likely they are to buy your product. The more senses you appeal to the more immersive the experience becomes and the easier it becomes to occupy part of your audiences mind for a longer period of time. ${ }^{99}$

Lawmakers should accept this new reality and facilitate its development especially when ' $[\mathrm{t}]$ echnology has reached a threshold whereby

\footnotetext{
University students along with their professor come up with an affordable device named oPhone that emits 32 scents that can be combined into more than 300,000 scents.

92 R Caula, 'Scent capturing postcard printer for Sony by Li jingxuan' (2012)

$<$ http://www.designboom.com/technology/scent-capturing-postcard-printer-for-sony-by-lijingxuan/> accessed 17.03.2017.

${ }_{93}$ Mackie (n 88) 438.

${ }^{94}$ Directive 2015/2436 of 16 December 2015, Art 3.

${ }^{95}$ Friedmann (n 71) 931-93.

${ }^{96}$ Mezulanik (n 82).

${ }^{97}$ Friedmann (n 71) 931-939.

${ }^{98}$ Case T-305/04 (CFI (Third Chamber) 27 October 2005), para 34.

${ }^{99}$ M Rivkin, 'Immersive Brand Experiences' (2015)

$<$ http://crucial-fx.com/consumer-behaviour/examples-of-the-best-immersive-brandexperiences/> accessed 18.03.2017.
} 
scents [along with colours and sounds] can be digitally encoded, thus travel the internet, be stored, downloaded and decoded by the emittance of scents via affordable scent printers connected to smart phones. This and other technologies will be assessed in light of the remaining Sieckmann representability requirements' ${ }^{\prime 00}$ (clear, precise, self-contained, easily accessible, intelligible, durable and objective) that are big enough for legal certainty and protection of customers.

In short, the non-traditional marks are becoming traditional (Colour and sound marks are even included in the trademark definition of the new EU Directive $^{101}$ ). For this reason lawmakers and officers of state agencies handling intellectual property identification should accept that the elephant in the room and do more to recognise certain sensory marks as registrable trademarks. The transposition of the revised EU Trademarks Directive that gets rid of the graphical representation requirement is the first step in a right direction that will 'kiss the registration of non-traditional trademarks back to life, to begin with sound marks.' ${ }^{102}$

\section{References}

\section{Legislation}

The Directive (EU) 2015/2436 of the European Parliament and of The Council of 16 December 2015 to approximate the laws of the Member States relating to trade marks.

Directive 2008/95/EC of the European Parliament and of the Council of 22 October 2008 to approximate the laws of the Member States relating to trade marks (Codified version) (Text with EEA relevance).

Lanham Act.

U.S. Constitution, Art 1., $§ 8, \mathrm{cl} .8$.

\section{Case law}

Case- 273/00 Sieckmann v Deutsches Patent-und Markenamt [2002] ECR I-11737.

Case R 781/1999-4.

Case T-305/04 (CFI (Third Chamber) 27 October 2005).

Edgar Rice Burroughs Inc. v OHIM; Case R708/2006-4.

Eli Lilly \& Co's Community Trade Mark Application, Case R 120/2001-2.

In re Clarke 17 U.S.P.Q. 2d (BNA) 1238 (T.T.A.B. 1990).

In re N.V. Organon, Serial No. 76467774.

New York Pizzeria, Inc. v Syal et al, No. 3:2013cv00335.

No. C-273/00, November 6, 2001.

Qualitex Co. v Jacobson Products Co., 514 U.S. 159 (1995) 162.

\section{Papers}

Arvidsson A, 'Brand Value' (2006) 13 Brand Management 188.

\footnotetext{
${ }^{100}$ Friedmann (n 71) 931-939.

${ }^{101}$ And can be consequently regarded as 'traditional' now.

102 ibid.
} 
Beebe B, (2005) Search and Persuasion in Trademark Law (2005) 103 Michigan Law Review 2030.

Bradford KD \& Desrochers DM, 'The use of scents to influence consumers: The sense of using scents to make cents' (2009) 90 Journal of Business Ethics 141-153.

Brown R jr, 'Advertising and the Public Interest: Legal Protection of Trade Symbols’ (1948) 57 Yale Law Journal 1182.

Daniel L, (2012) 'Distinctive sounds like the MGM lion's roar protected by law' (2012) Montreal Gazette (10 February 2012).

Davies BJ, Kooijman D \& Ward P, 'The Sweet Smell of Success: Olfaction in Retailing' (2003) 611 Journal of Marketing Management, 622623.

Mezulanik E, 'The Status of Scents as Trademarks: An International Perspective' (2012) IntaBulletin (1 January 2012).

Friedmann D, 'EU Opens Door for Sound Marks: Will Scent Marks Follow?' (2015) 10.12 Journal of Intellectual Property Law \& Practice 931, 931-939.

Garlin FV \& Owen K, 'Setting the tone with a tune: a meta-analytic review of the effects of background music in retail settings' (2006) 59 Journal of Business Research 755-764.

Girard M, Girard A, Suppin A-C, Bartsch S, 'The Scentscape: An Integrative Framework Describing Scents in Servicescapes' (2016) 9 Journal of Business Market Management, 597-622.

Hirsch AR, 'Effects of ambient odors on slot-machine usage in a Las Vegas casino' (1995) 12 Psychology and Marketing 585-594.

Hultén B, 'Sensory marketing: the multi-sensory brand-experience concept' (2011) 23.1 European Business Review 256 - 273.

Karapapa S, 'Registering Scents as Community Trademarks' (2010) 100.6 The Trademark Reporter 1335-1359, 1336.

Krishna A, Lwin MO \& Morrin M, 'Product scent and memory' (2010) 37.1 Journal of Consumer Research 57.

Lince T, 'Taste trademarks set to remain on the shelf (2014) World Trademark Review (07.11.2014).

Lindstroem M, Brand Sense: Build Powerful Brands Through Touch, Taste, Smell, Sight and Sound (Free Press 2005).

Lwin MO \& Morrin M, 'Scenting movie theatre commercials: The impact of scent and pictures on brand evaluations and ad recall: Scented cinema ads' (2012) 11 Journal of Consumer Behaviour 264-272.

Mackie V, 'Scent Marks. The Future of Canadian Trade-Mark Law' (2004/2005) Intellectual Property Journal 417, 438.

Peck J \& Wiggins J, 'It just feels good: customers' affective response to touch and its influence on persuasion' (2006) 70 Journal of Marketing 5669.

Rimkute J, Moraes C \& Ferreira C, The effects of scent on consumer behaviour (2016) 40 International Journal of Consumer Studies 33.

Stoakes C, Commercial Awareness (Christopher Stoakes Ltd 2014) 7.

\section{Miscellaneous Documents}

Binns C, 'How we smell' (2006) LifeScience. 
Byron E, 'The Search for Sweet Sounds That Sell' The Wall Street Journal (24 October 2012). (2012).

Caula R, 'Scent capturing postcard printer for Sony by Li jingxuan'

Gershmann J, 'Eau de Fracking? Companies Try to Trademark Scents' The Wall Street Journal (14 April 2015).

McLaughlin J, 'What is brand, anyway?' Forbes (2011).

Rivkin M, Immersive Brand Experiences (2015).

'Smell, Sound and Taste - Getting a Sense of Non-Traditional Marks' WIPO Magazine (February 2002).

'The Science of Sensory Marketing' Harvard Business Review (March 2015).

'The smell of commerce: How companies use scents to sell their products' Independent (15 August 2011).

Süskind P, Perfume: The Story of a Murderer (1985).

Wassom B, 'A Distinctive Touch: Augmented Textures and Haptic Trademarks' (2011)

Zaitseva A, 'Challenging Aspects of Protecting of Non-Traditional Trademarks: The Five Senses and Trademarks' (IPWatchdog, 02.03.2017).

\section{Other Resources}

Barron A, 'LL4BR: Branding and Trademarks' seminars', The London School of Economics and Political Science (2016-2017). 